\title{
Non-Indigenous Species on Artificial Coastal Environments: Experimental Comparison between Aquaculture Farms and Recreational Marinas
}

\author{
Lydia Png-Gonzalez ${ }^{1,2, *(\mathbb{D})}$, Patrício Ramalhosa ${ }^{2,3}$ (D) $_{\text {, Ignacio Gestoso }}^{3,4}$ (D), Soledad Álvarez ${ }^{3}$ (D) \\ and Natacha Nogueira 5,6
}

1 Centro Oceanográfico de Baleares (IEO, CSIC), Muelle de Poniente s/n, 07015 Palma de Mallorca, Spain

2 Oceanic Observatory of Madeira, Agência Regional para o Desenvolvimento da Investigação Tecnologia e Inovação, Edifício Madeira Tecnopolo, Caminho da Penteada, 9020-105 Funchal, Portugal; pramalhosa@mare-centre.pt

3 Marine and Environmental Sciences Centre, Agência Regional para o Desenvolvimento da Investigação Tecnologia e Inovação, Edifício Madeira Tecnopolo, Caminho da Penteada, 9020-105 Funchal, Portugal; igestoso@mare-centre.pt (I.G.); soledadalvarezsuarez@mare-centre.pt (S.Á.)

4 Smithsonian Environmental Research Center, 647 Contees Wharf Road, Edgewater, MD 21037, USA

5 Regional Directorate for the Sea, Lota do Funchal, Rua Virgílio Teixeira, 9004-562 Funchal, Portugal; natacha.nogueira@madeira.gov.pt

6 Interdisciplinary Centre of Marine and Environmental Research, Av. General Norton de Matos, 4450-238 Matosinhos, Portugal

* Correspondence: lydiapng@gmail.com

Citation: Png-Gonzalez, L.; Ramalhosa, P.; Gestoso, I.; Álvarez, S.; Nogueira, N. Non-Indigenous Species on Artificial Coastal Environments: Experimental Comparison between Aquaculture Farms and Recreational Marinas. J. Mar. Sci. Eng. 2021, 9, 1121.

https://doi.org/10.3390/jmse9101121

Academic Editor: Gianluca SARA'

Received: 21 September 2021

Accepted: 11 October 2021

Published: 14 October 2021

Publisher's Note: MDPI stays neutral with regard to jurisdictional claims in published maps and institutional affiliations.

Copyright: (c) 2021 by the authors. Licensee MDPI, Basel, Switzerland. This article is an open access article distributed under the terms and conditions of the Creative Commons Attribution (CC BY) license (https:// creativecommons.org/licenses/by/ $4.0 /)$.

\begin{abstract}
Globally, there is growing concern regarding the effects of the increasing anthropogenic pressures in marine communities. Artificial structures such as marinas and aquaculture facilities serve as invasion hotspots; hence, monitoring fouling communities on these structures can be valuable for detecting new invasions. In the current study, 24 settlement PVC plates were deployed for three months to compare the recruitment ability of these two artificial environments along the south coast of the offshore island of Madeira (NE Atlantic). The results showed higher variations in the species richness between regions (SW vs. SE) than between artificial habitats (sea-cages vs. marinas), although the community composition differed. Cnidaria and Bryozoa were the most representative groups in the aquaculture systems, while Bryozoa and Chordata were in the marinas. A sum of 18 NIS was recorded for the study, accounting for between $21.88 \%$ and $54.84 \%$ of the total number of species in the aquaculture facilities and marinas, respectively. The higher NIS percentage from the marinas was even more explicit in the SE coast, where Cradoscrupocellaria bertholletii, Parasmittina alba, and Botrylloides niger distinctly dominated fouling populations. The results suggest that at least some particular NIS previously reported in the studied marinas successfully colonized sea-cages. Future assessments need to address the potential role of aquaculture facilities as drivers for the secondary spread of NIS. Additionally, two new records are considered for Madeira: Eudendrium capillare and Ericthonius punctatus.
\end{abstract}

Keywords: biofouling; artificial substrate; sea-cages; shipping; Madeira; Macaronesia

\section{Introduction}

Aquaculture is considered a growing activity worldwide and the outermost regions such as Macaronesia, where the physical and oceanographic conditions contribute to fish farming activities in open waters [1], are not an exception. As part of the Macaronesian region, the Madeira Archipelago presents stable temperatures throughout the year $\left(17-24{ }^{\circ} \mathrm{C}\right)$ and a narrow continental shelf, rapidly increasing the depth near the coastline [2,3]. Therefore, high-energy environments are easily found close to the coast $(0.3-1.0 \mathrm{~km})$, supporting the deployment of floating fish cages as the main aquaculture method in the region and increasing the production from $386 \mathrm{Tn}$ in 2015 to $1234.6 \mathrm{Tn}$ in 2020 [4]. 
Marine fish aquaculture operations consist of various floating and submerged structures (i.e., platforms, circular plastic rings, buoys, ropes, and nets), mainly classified as artificial polymer materials, which also serve as surfaces for biofouling colonization and settlement [5]. Biofouling on these artificial habitats is one of the main barriers to efficient and sustainable production [6,7], involving negative impacts (e.g., increasing drag forces on fish cages and restricting the water exchange through nets that could compromise the fish behavior and health) [8,9] with additional economic costs to the industry [10]. Moreover, fouling species in aquaculture cages may serve as a supplementary food source for the cultured fish and farm-associated species, stimulating the inspection and bites on the net that can lead on to more significant damages, such as escapes [11,12].

Due to the ongoing increase of aquaculture and trade, offshore aquaculture activities are also critical for facilitating the local dispersion of non-indigenous species (NIS) [13,14], which are well-known serious environmental threats [15] and considered among the primary threats to global biodiversity and ecosystem function $[16,17]$. These artificial substrates may serve as stepping stones, offering novel niches for opportunistic colonizers, including NIS, favoring their dispersal [18] and supplying the substrate to establish other NIS [19], with potential ecological impacts [20-22]. Consequently, the study of fouling communities on aquaculture structures may likewise contribute to detecting NIS arrivals and updating their distribution patterns [23].

A wide range of literature has characterized the fouling communities for many regions of the world on different aquaculture production systems and associated structures, such as buoys [24], ropes [5], or fish-cage nets [25]. Depending upon the study's aims, the choice of the method to quantify and/or identify the biofouling assemblages differs, but so far, the studies dealing with the characterization of biofouling assemblages, including the detection and richness of NIS on these artificial substrates remain scarce, especially in the North eastern Atlantic region.

Besides aquaculture substrates, several studies have been carried out in other anthropogenic structures, namely ports and recreational marinas, to assess the distribution and diversity of NIS [26-28], as these structures play an important role as main hubs for the introduction of NIS via the maritime transport [29-31]. Recently, Giangrande et al. [32] analyzed and compared the fouling communities found on several artificial substrates, including pontoons, quays, and ropes of a fish aquaculture facility of an enclosed part of the Mar Grande of Taranto (Ionian Sea). The authors concluded that the assemblages differed according to the age and size of the substrate, but also to their distance and depth from the fish aquaculture facility, as a proxy of organic enrichment.

In recent years, the Madeira Archipelago has been the site of a comprehensive monitoring survey of marine NIS using PVC plates in marinas [33-37]. This methodology, also used by several other authors [28,38-40], has turned out to be a sensitive and reliable option to measure NIS across different habitats.

The aims of the present study were, for the first time, (i) to describe and analyze the fouling community settled on experimental PVC plates in two aquaculture facilities located along the south coast of Madeira island and (ii) to compare the fouling communities with the ones found in recreational marinas. By standardizing the substrate and time of exposure in these two different but very closely situated artificial environments, we aimed to compare the variability in the macrofouling's recruitment process, including the community composition and to detect the occurrence of NIS.

\section{Materials and Methods}

\subsection{Study Area and Sampling Design}

The study was carried out in two regions along the south coast (SW and SE) of Madeira Island (Portugal, NE Atlantic; Figure 1). In each region, the experiment was performed in two different artificial environments: (a) an aquaculture facility devoted to the growing of gilthead sea bream (Sparus aurata) and (b) one recreational marina located in the closest 
bay. The distance between the SE marina and the respective aquaculture operation was approximately $1 \mathrm{~km}$, whereas the distance reached nearly $4 \mathrm{~km}$ in the SW region.

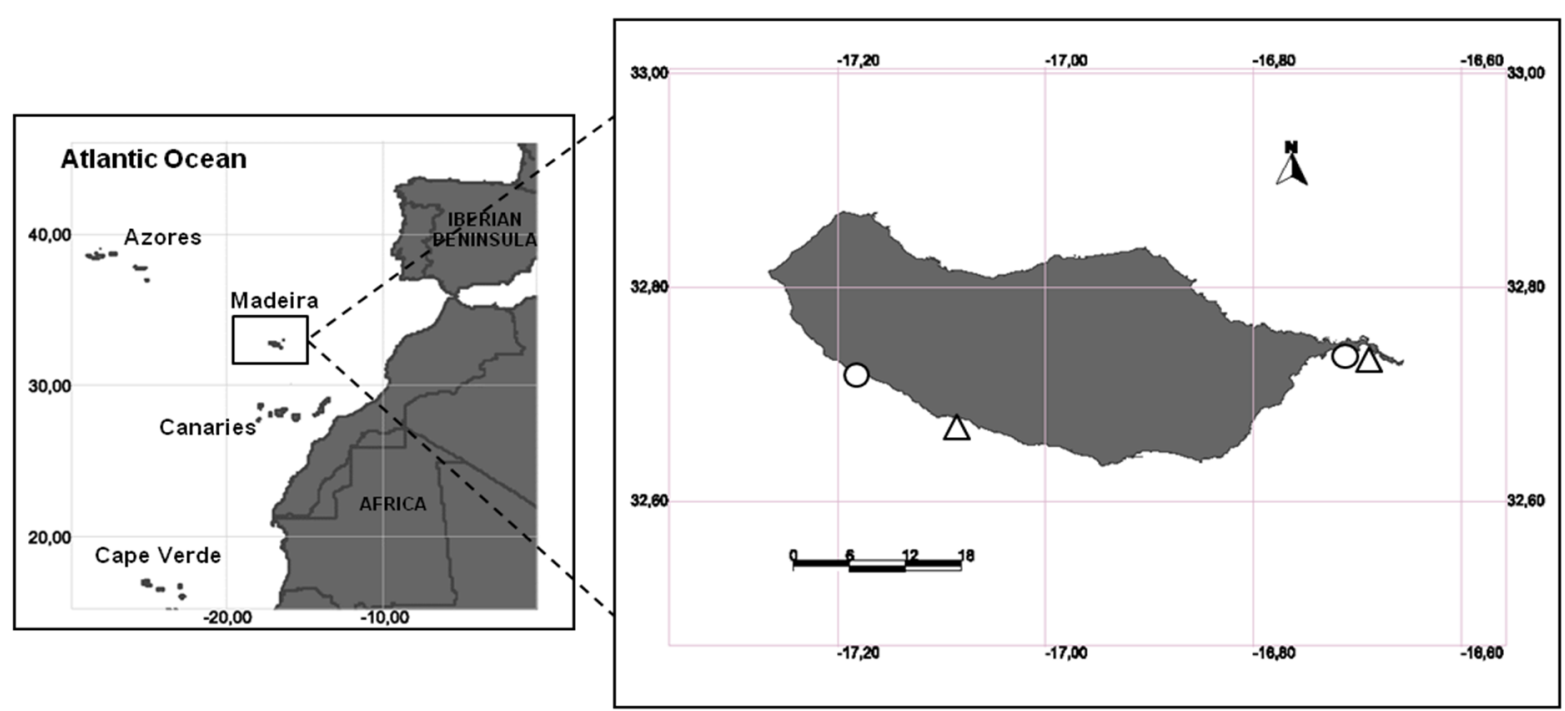

Figure 1. Study regions in Madeira along the southern coast. Triangles, aquaculture facilities; circles, marinas.

Based on the design employed by Canning-Clode et al. [41] and Ramalhosa et al. [42], a total of 24 PVC plates $(14 \times 14 \times 0.3 \mathrm{~cm})$ were horizontally attached to a brick and faced downwards to favor the recruitment of macroinvertebrates, rather than macroalgae (Figure S1). All replicates ( $n=6$ per study region) were submerged at approximately 1-m depth from the external float of the sea-cages (Figure S2) and marina's pontoons (Figure S3), with a minimum distance of $5 \mathrm{~m}$ between replicates. After three months (August-November 2018), experimental plates were retrieved to collect representative samples of mature communities and plates were photographed (out of the water with bottom face up) using an Olympus TG-5 camera (Figure S4).

In the laboratory, benthic species settled on the plates were identified and confirmed using a stereomicroscope (Leica S8APO) to account for total species richness. All sessile macroinvertebrates and algae were identified to the lowest possible taxonomic level and later assigned to four biogeographic categories: native, NIS, cryptogenic (i.e., unspecified origin; [43]), or unresolved (based on an inability to identify to species level). In all data analyses, the NIS status was attributed only to those species with a confirmed nonindigenous category and verified by specific scientific literature [33,36,44,45].

The biogeographical status (NIS, cryptogenic, unresolved, and native) of the fouling communities was compared between marinas and sea-cages. To evaluate the NIS settlement success on experimental plates, a more conservative approach was followed [35,36], and those species categorized as cryptogenic and unresolved were included within the native species for the statistical analyses.

Previous photographs taken from the plates were used to determine species richness and total percent cover by using the image analysis software CPCe [46]. Consequently, each image was sub-divided into $3 \times 3$ grids of 9 cells, with 11 random points per cell, resulting in 99 points analyzed per picture. This stratified random sampling method ensured that points were sampled in each region of the image [46], as it has been successfully developed in recent sampling analyses $[36,41,44]$.

\subsection{Statistical Analyses}

Univariate analyses were performed considering the total percent cover and species richness of the overall species (i.e., total, NIS, and native species) between regions and environments. A 2-way permutational ANOVA was used and included the orthogonal factors: 'Region' (random factor with 2 levels: SW and SE), and 'Environment' (fixed factor 
with 2 levels: sea-cages and marinas; $n=6$ ). A PERMDISP test was used to assess the data for heterogeneity of dispersions, and transformations were applied when necessary. Analyses were based on Euclidean distances, using an approach similar to parametric ANOVA [47]. $p$-values for the pseudo- $F$ ratios were calculated by permutation of raw data through 9999 permutations. Significant effects $(p<0.05)$ were further investigated through pairwise comparisons between treatments. Pooling procedures were used where appropriate $(>0.25)$ to improve the power of tests concerning terms of interest [48].

Differences in the multivariate structure of the fouling community (composition and abundance) were visualized through a Non-metric Multidimensional Scaling (nMDS) plot to evaluate the community assembling responses to different artificial environments (i.e., sea-cages vs. marinas). The significance of multivariate differences was tested by a two-way PERMANOVA, following the same design outlined above, and analyses were based on Bray-Curtis similarities. Finally, to explain the community changes, taxa that contributed most to similarity within and dissimilarity among groups were identified using SIMPER analysis [49]. All statistical analyses were performed using the software PRIMER v6 [50,51] with the PERMANOVA+ for PRIMER (PRIMER-E Ltd., Plymouth, UK).

\section{Results}

A total of 54 species was found on the experimental plates (Table 1), belonging to 7 different phyla: Bryozoa (18), Chordata (10), Cnidaria (8), Crustacea (5), Porifera (5), Annelida (4), and Macroalgae (4). Of these taxa, 10 were categorized as native (16.7\%), 18 as NIS (33.3\%), 15 as cryptogenic $(29.6 \%)$, and 11 were considered as unresolved $(20.4 \%)$. The average species richness within each artificial environment was $25 \pm 10$ species for the aquaculture sea-cages and $29 \pm 4$ species for the marinas. In the aquaculture installations, Cnidaria was the most representative group $(R=5)$ in the SW location, followed by Porifera $(R=4)$, while Bryozoa $(R=9)$ and Cnidaria $(R=7)$ were in the SE location (Table 1 ; Figure 2$)$. On the other hand, Bryozoa $(R=8$ in the SW and $R=11$ in the SE) and Chordata $(R=7$ in each region; Table 1 ; Figure 2) were the most representative phyla of both recreational marinas.

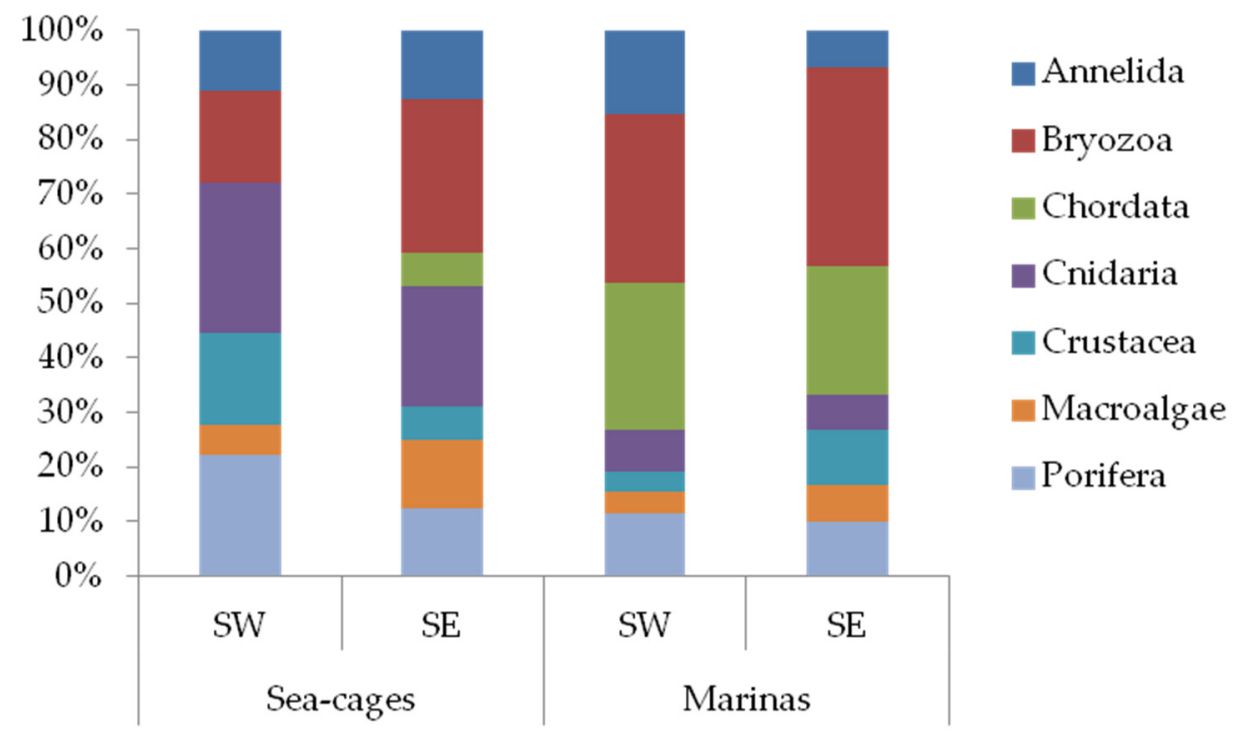

Figure 2. Taxa contributions for similarity among plates (SIMPER, 100\% stacked column, $n=6$ ) in 3-month-old experimental plates for each type of artificial environment (sea-cages vs. marinas) and region (SW vs. SE). 
Table 1. List of recorded species found in sea-cages and marinas located on the south coast of Madeira. Taxa were categorized as native (N), non-indigenous species (NIS), cryptogenic (C), or unresolved (U). Filled symbols, present; open symbols, absent.

\begin{tabular}{|c|c|c|c|c|c|c|}
\hline \multirow{2}{*}{ Taxa } & \multirow{2}{*}{ Status } & \multirow{2}{*}{ Sources } & \multicolumn{2}{|c|}{ Sea-Cages } & \multicolumn{2}{|c|}{ Marinas } \\
\hline & & & SW & SE & SW & SE \\
\hline \multicolumn{7}{|l|}{ Annelida (4) } \\
\hline Protula tubularia (Montagu, 1803) & $\mathrm{C}$ & {$[36,52]$} & 0 & $\bullet$ & $\bullet$ & 0 \\
\hline Salmacina dysteri (Huxley, 1855) & $\mathrm{N}$ & {$[33,52,53]$} & $\bullet$ & $\bullet$ & • & $\bullet$ \\
\hline Spirobranchus triqueter (Linnaeus, 1758) & $\mathrm{N}$ & {$[36,44]$} & $\bullet$ & $\bullet$ & $\bullet$ & $\bullet$ \\
\hline Spirorbis sp. & $\mathrm{U}$ & & 0 & $\bullet$ & $\bullet$ & $\bullet$ \\
\hline \multicolumn{7}{|l|}{ Bryozoa (18) } \\
\hline Aetea sica (Couch, 1844) & $\mathrm{C}$ & [54] & 0 & $\bullet$ & 0 & 0 \\
\hline Amathia verticillata (delle Chiaje, 1822) & NIS & {$[36,46,55]$} & 0 & 0 & $\bullet$ & 0 \\
\hline Bugula sp. Oken, 1815 & $\mathrm{U}$ & & $\bullet$ & 0 & 0 & 0 \\
\hline Bugula neritina (Linnaeus, 1758) & NIS & {$[36,54,56]$} & 0 & 0 & $\bullet$ & $\bullet$ \\
\hline Bugulina simplex (Hincks, 1886) & NIS & {$[36,56]$} & 0 & 0 & $\bullet$ & $\bullet$ \\
\hline $\begin{array}{l}\text { Celleporaria inaudita Tilbrook, Hayward and } \\
\text { Gordon, } 2001\end{array}$ & NIS & {$[33,36,57]$} & $\bigcirc$ & O & O & $\bullet$ \\
\hline $\begin{array}{l}\text { Cradoscrupocellaria bertholletii } \\
\text { (Audouin, 1826) }\end{array}$ & NIS & {$[33,36,46]$} & 0 & $\bullet$ & $\bullet$ & $\bullet$ \\
\hline Crisia sp. Lamouroux, 1812 & $\mathrm{U}$ & & $\bullet$ & $\bullet$ & $\bullet$ & $\bullet$ \\
\hline Fenestrulina sp. Jullien, 1888 & $\mathrm{U}$ & & 0 & 0 & 0 & $\bullet$ \\
\hline Nolella gigantea (Busk, 1856) & $\mathrm{C}$ & [36] & $\bigcirc$ & $\bullet$ & $\bigcirc$ & $\bigcirc$ \\
\hline $\begin{array}{l}\text { Parasmittina alba Ramalho, Muricy and } \\
\text { Taylor, } 2011\end{array}$ & NIS & {$[36,57]$} & $\bigcirc$ & $\bigcirc$ & $\bullet$ & $\bullet$ \\
\hline Schizoporella errata (Waters, 1878) & $\mathrm{C}$ & [36] & $\bigcirc$ & $\bullet$ & $\bullet$ & $\bullet$ \\
\hline Scruparia sp. Oken, 1815 & $\mathrm{U}$ & & 0 & $\bullet$ & 0 & 0 \\
\hline Scrupocaberea maderensis (Busk, 1860) & $\mathrm{N}$ & {$[54,58]$} & 0 & 0 & 0 & $\bullet$ \\
\hline Scrupocellaria sp. Van Beneden, 1845 & $\mathrm{U}$ & & $\bullet$ & 0 & 0 & 0 \\
\hline Smittoidea sp. Osburn, 1952 & $\mathrm{U}$ & & 0 & $\bullet$ & 0 & $\bullet$ \\
\hline Tricellaria sp. Fleming, 1828 & $\mathrm{U}$ & & 0 & $\bullet$ & 0 & 0 \\
\hline Watersipora subtorquata (d'Orbigny, 1852) & NIS & {$[33,36,46]$} & 0 & $\bullet$ & $\bullet$ & $\bullet$ \\
\hline \multicolumn{7}{|l|}{ Chordata $(10)$} \\
\hline Aplidium glabrum (Verrill, 1871) & NIS & {$[36,37]$} & 0 & 0 & $\bullet$ & 0 \\
\hline Botrylloides niger Herdman, 1886 & NIS & {$[36,37]$} & 0 & $\bigcirc$ & $\bullet$ & $\bullet$ \\
\hline Botryllus schlosseri (Pallas, 1766) & NIS & {$[33,36,37]$} & 0 & $\bullet$ & $\bullet$ & O \\
\hline Diplosoma listerianum (Milne Edwards, 1841) & C & {$[36,37,44]$} & 0 & $\bullet$ & 0 & $\bullet$ \\
\hline Distaplia corolla Monniot F., 1974 & NIS & {$[33,36,37,44]$} & 0 & 0 & $\bullet$ & $\bullet$ \\
\hline Ecteinascidia sp. Herdman, 1880 & $\mathrm{U}$ & [37] & 0 & 0 & 0 & $\bullet$ \\
\hline Perophora listeri Wiegman, 1835 & $\mathrm{C}$ & {$[36,37]$} & $\bigcirc$ & $\bigcirc$ & $\bullet$ & $\bullet$ \\
\hline Symplegma rubra Monniot C., 1972 & $\mathrm{C}$ & {$[36,37]$} & 0 & 0 & $\bullet$ & 0 \\
\hline Symplegma brakenhielmi (Michaelsen, 1904) & $\mathrm{C}$ & {$[37,44]$} & 0 & 0 & 0 & $\bullet$ \\
\hline Trididemnum cereum (Giard, 1872) & $\mathrm{C}$ & {$[33,36,37]$} & 0 & $\bigcirc$ & $\bullet$ & $\bullet$ \\
\hline \multicolumn{7}{|l|}{ Cnidaria (8) } \\
\hline Aiptasia diaphana (Rapp, 1829) & NIS & {$[33,37]$} & 0 & $\bullet$ & 0 & $\bullet$ \\
\hline Clytia hemisphaerica (Linnaeus, 1767) & $\mathrm{C}$ & [59] & 0 & $\bullet$ & 0 & 0 \\
\hline Ectopleura crocea (Agassiz, 1862) & NIS & {$[46,59,60]$} & $\bullet$ & $\bullet$ & 0 & 0 \\
\hline Eudendrium capillare Alder, 1856 & $\mathrm{C}$ & This study & $\bullet$ & 0 & 0 & 0 \\
\hline Kirchenpaueria halecioides (Alder, 1859) & $\mathrm{C}$ & {$[36,59]$} & $\bullet$ & $\bullet$ & $\bullet$ & $\bullet$ \\
\hline Obelia dichotoma (Linnaeus, 1758) & $\mathrm{C}$ & {$[36,59]$} & $\bullet$ & $\bullet$ & 0 & 0 \\
\hline Pennaria disticha Goldfuss, 1820 & $\mathrm{C}$ & {$[36,59]$} & $\bullet$ & $\bullet$ & 0 & 0 \\
\hline $\begin{array}{l}\text { Sertularella ellisii (Deshayes and Milne } \\
\text { Edwards, 1836) }\end{array}$ & $\mathrm{C}$ & {$[59,61]$} & 0 & $\bullet$ & $\bullet$ & $\bigcirc$ \\
\hline
\end{tabular}


Table 1. Cont.

\begin{tabular}{|c|c|c|c|c|c|c|}
\hline \multirow{2}{*}{ Taxa } & \multirow{2}{*}{ Status } & \multirow{2}{*}{ Sources } & \multicolumn{2}{|c|}{ Sea-Cages } & \multicolumn{2}{|c|}{ Marinas } \\
\hline & & & SW & SE & SW & SE \\
\hline \multicolumn{7}{|l|}{ Crustacea (5) } \\
\hline Caprella scaura Templeton, 1836 & NIS & {$[34,36]$} & 0 & 0 & 0 & $\bullet$ \\
\hline Chthamalus stellatus (Poli, 1791) & $\mathrm{N}$ & [62] & $\bullet$ & 0 & 0 & 0 \\
\hline Ericthonius punctatus (Spence Bate, 1857) & $\mathrm{C}$ & This study & $\bullet$ & $\bullet$ & $\bullet$ & $\bullet$ \\
\hline Megabalanus azoricus (Pilsbry, 1916) & $\mathrm{N}$ & [63] & $\bullet$ & $\bullet$ & 0 & 0 \\
\hline Paracerceis sculpta (Holmes, 1904) & NIS & {$[64]$} & $\bigcirc$ & $\bigcirc$ & $\bigcirc$ & $\bullet$ \\
\hline \multicolumn{7}{|l|}{ Macroalgae (4) } \\
\hline Bryopsis sp. J.V. Lamouroux, 1809 & $\mathrm{U}$ & & 0 & $\bullet$ & 0 & 0 \\
\hline Champiaceae sp. Kützing, 1843 & $\mathrm{U}$ & & 0 & $\bullet$ & 0 & 0 \\
\hline Lithophyllum incrustans Philippi, 1837 & $\mathrm{~N}$ & {$[33,36,65]$} & $\bullet$ & $\bullet$ & $\bullet$ & $\bullet$ \\
\hline $\begin{array}{l}\text { Neosiphonia sertularioides (Grateloup) K.W. } \\
\text { Nam and P.J. Kang, } 2012\end{array}$ & $\mathrm{~N}$ & {$[33,36,66]$} & $\bigcirc$ & $\bullet$ & $\bigcirc$ & $\bullet$ \\
\hline \multicolumn{7}{|l|}{ Porifera (5) } \\
\hline Clathrina clathrus (Schmidt, 1864) & $\mathrm{N}$ & [36] & • & $\bullet$ & 0 & 0 \\
\hline Mycale (Carmia) senegalensis Lévi, 1952 & NIS & {$[33,36,44]$} & $\bullet$ & $\bullet$ & $\bullet$ & $\bullet$ \\
\hline $\begin{array}{l}\text { Paraleucilla magna Klautau, Monteiro and } \\
\text { Borojevic, } 2004\end{array}$ & NIS & {$[33,36,44]$} & $\bullet$ & $\bullet$ & $\bigcirc$ & $\bullet$ \\
\hline Prosuberites longispinus Topsent, 1893 & NIS & [36] & 0 & 0 & $\bullet$ & 0 \\
\hline Sycon ciliatum (Fabricius, 1780) & $\mathrm{N}$ & {$[33,36,67]$} & $\bullet$ & $\bullet$ & $\bullet$ & $\bullet$ \\
\hline \multirow{2}{*}{ Total Species Richness } & \multirow{2}{*}{54} & $\begin{array}{l}\text { Total species } \\
\text { per region }\end{array}$ & 18 & 32 & 26 & 31 \\
\hline & & Percentage (\%) & 33.3 & 59.3 & 48.1 & 57.4 \\
\hline
\end{tabular}

Only eight species were found in common between the study regions (Table 1): Salmacina dysteri, Spirobranchus triqueter (Annelida); Crisia sp. (Bryozoa); Kirchenpaueria halecioides (Cnidaria); Ericthonius punctatus (Crustacea); Lithophyllum incrustans (Macroalgae); Mycale (Carmia) senegalensis, and Sycon ciliatum (Porifera). It should be mentioned that, besides the sessile fauna, some vagile species were found and therefore considered, given their cryptogenic and NIS status (i.e., Caprella scaura, E. punctatus, and Paracerceis sculpta; Table 1). However, these species were not representative of the whole epifaunal community, which was underestimated with the following methodology. Additionally, two new records were considered for Madeira with Eudendrium capillare and E. punctatus, which were then deposited at the Natural History Museum of Funchal (MMF), Madeira (under voucher number MMF48340 and MMF47931/MMF47932, respectively).

Univariate analyses showed that the total percentage cover of fouling communities was affected by the region and the type of artificial environment (significant interaction:

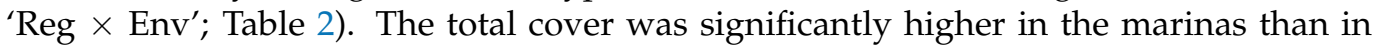
the sea-cages, but only for the SW coast (Figure 3a). The type of artificial environment (sea-cages vs. marinas) significantly altered both the native and NIS cover, promoting a higher cover of native communities in both aquaculture facilities, while the NIS cover was significantly higher in the marinas (Table 2; Figure 3a). The total and native species richness were more affected by spatial differences than between the types of artificial environments (Table 2), as fouling assemblages maintained significantly higher values for both response variables in the SE coast (Figure 3b). By contrast, NIS richness was significantly affected by the artificial environment, presenting higher richness in both marinas (Table 2; Figure 3b), with the highest number of NIS found in the SE region. 
Table 2. Results of 2-way PERMANOVA testing for variability in fouling community composition, and 2-way permutational ANOVA examining changes in percent cover and species richness of total community, native species, and non-indigenous species (NIS; $n=6$ ).

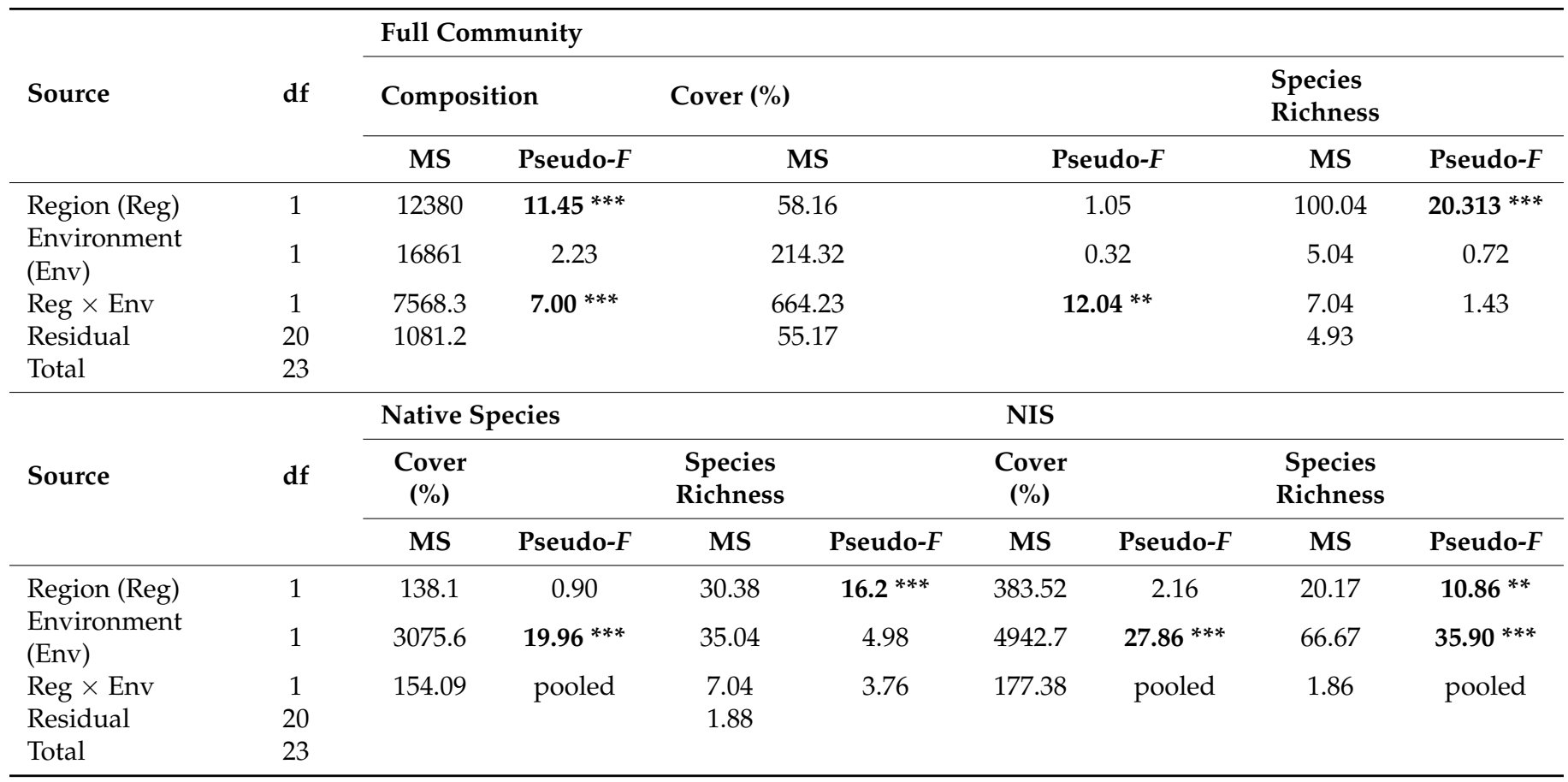

${ }^{*} p<0.05,{ }^{* *} p<0.01,{ }^{* * *} p<0.001$. Significant $p$-values are indicated in bold.
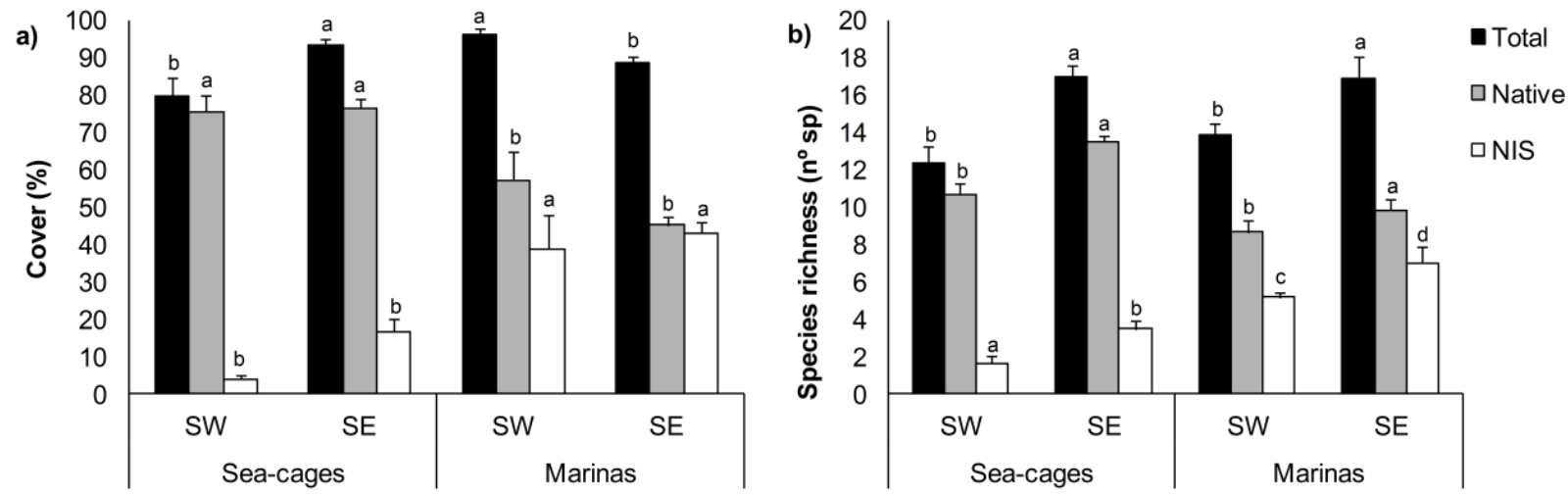

Figure 3. (a) Mean cover $(\%+\mathrm{SE})$ and (b) species richness (mean $+\mathrm{SE})$ of total, native, and non-indigenous species (NIS) across artificial environments (sea-cages vs. marinas) and regions (SW vs. SE). Significances of $a$ posteriori pairwise tests between regions within environments are indicated with different letters $(p<0.05)$.

Multivariability associated with the two regions induced significant differences in the type of fouling communities recruited on the plates deployed in the sea-cages compared to those deployed in the marinas (significant interaction: 'Reg $\times$ Env'; Table 2). Clear segregation from sea-cages communities vs. marinas communities can be appreciated in the nMDS: fouling assemblages associated with aquaculture sea-cages are on the left-hand side of the ordination space, while assemblages inhabiting recreational marinas are on the right-hand side of the plot (Figure 4). Posteriori pairwise comparisons confirmed significant differences between communities from sea-cages and marinas in both regions, but the effect of the marina environment was stronger in the SE than in the SW (similarities marina group: 53.3 vs. 37.8; Table 2; Figure 4). 


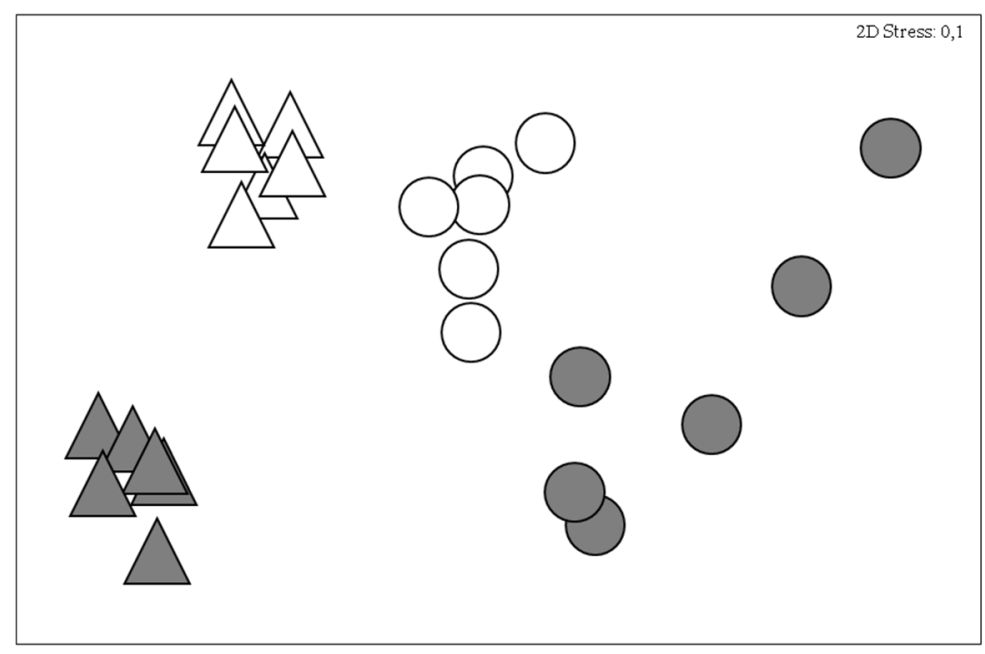

Figure 4. Two-dimensional n-MDS plot showing similarities of fouling communities between artificial environments and regions $(n=6)$. Triangles, sea-cages; circles, marinas. Filled symbols, SW; open symbols, SE.

Finally, SIMPER analysis revealed the most critical taxa contributing to the communities' dissimilarity and similarity between each type of artificial environment (i.e., contribution $\geq 2 \%$; Table 3). The bryozoans Scrupocellaria sp. and Crisia sp. were the most important taxa in shaping differences between the recruited communities in the SW coast and only Botrylloides niger, particularly abundant in the marina, was remarkable among the NIS recruited (Table 3a). By contrast in the SE region, and though the most important species in separating communities was the cryptogenic amphipod E. punctatus, the contribution of the NIS Parasmittina alba and B. niger was particularly relevant, summing together more than $18 \%$ of the total dissimilarity (Table 3a). SIMPER analysis highlighted the taxa Scrupocellaria sp. and E. punctatus as those mostly contributing to similarity within sea-cages in the SW and SE regions, respectively (Table $3 \mathrm{~b}$ ). Similarity results also revealed the bryozoan Crisia sp. as the second most important species in the sea-cages, and in this case, affecting the communities from both regions (25.42\% in the SW and $15.19 \%$ in the SE). Communities in the marina environments showed important abundances of NIS, namely in the SE coast $(41.46 \%)$ compared to the SW $(22.18 \%)$, where Cradoscrupocellaria bertholletii, Botrylloides niger, and Parasmittina alba distinctly dominated fouling populations. However, in the SW region, none of the three taxa contributing higher to the similarity of communities from the respective marina was catalogued as NIS $(43.40 \%$ summed by S. disteri, Spirorbis sp. and Schizoporella errata). Sea-cages presented some contribution of NIS, especially in the SE region ( $14.04 \%$ vs. $6.27 \%$ in the SW), but to a much lower extent than the closest marina in both regions (Table $3 b$ ). 


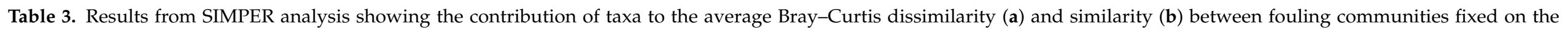

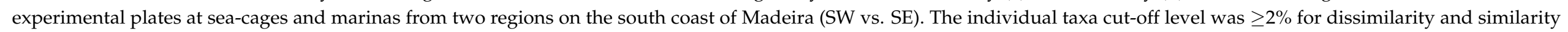
analyses. Non-indigenous species are highlighted in bold.

\begin{tabular}{|c|c|c|c|c|c|c|c|c|}
\hline \multirow{2}{*}{ (a) } & \multirow{2}{*}{ Area } & \multirow{2}{*}{ Taxon } & \multicolumn{2}{|l|}{ Sea-Cages } & \multirow[b]{2}{*}{ Av.Diss } & \multirow[b]{2}{*}{ Diss/SD } & \multirow[b]{2}{*}{ Contrib\% } & \multirow[b]{2}{*}{ Cum $\%$} \\
\hline & & & Av.Abund & Av.Abund & & & & \\
\hline & \multirow[t]{13}{*}{ SW } & Scrupocellaria sp. & 20.03 & 0.00 & 11.40 & 5.90 & 12.80 & 12.80 \\
\hline & & Crisia sp. & 19.36 & 1.01 & 10.29 & 2.56 & 11.55 & 24.35 \\
\hline & & Botrylloides niger & 0.00 & 17.34 & 9.76 & 0.77 & 10.96 & 35.31 \\
\hline & & Symplegma rubra & 0.00 & 11.28 & 6.69 & 0.68 & 7.50 & 42.81 \\
\hline & & Eudendrium sp. & 11.78 & 0.00 & 6.66 & 3.07 & 7.48 & 50.29 \\
\hline & & Schizoporella errata & 0.00 & 10.27 & 5.85 & 1.23 & 6.57 & 56.86 \\
\hline & & Spirorbis sp. & 0.00 & 9.76 & 5.64 & 1.49 & 6.33 & 63.19 \\
\hline & & Salmacina dysteri & 0.34 & 8.59 & 4.79 & 1.82 & 5.38 & 68.57 \\
\hline & & Prosuberiteslongispinus & 0.00 & 7.24 & 4.06 & 0.73 & 4.55 & 73.12 \\
\hline & & Parasmittina alba & 0.00 & 5.56 & 3.19 & 1.00 & 3.58 & 76.70 \\
\hline & & Lithophyllum incrustans & 8.42 & 5.72 & 2.91 & 1.34 & 3.26 & 79.96 \\
\hline & & Ectopleura crocea & 3.70 & 0.00 & 2.07 & 1.44 & 2.32 & 82.28 \\
\hline & & Ericthonius punctatus & 1.85 & 4.71 & 1.84 & 1.28 & 2.07 & 84.35 \\
\hline & \multirow[t]{10}{*}{ SE } & Ericthonius punctatus & 24.91 & 3.87 & 11.59 & 3.13 & 16.93 & 16.93 \\
\hline & & Parasmittina alba & 0.00 & 12.46 & 6.87 & 0.98 & 10.03 & 26.97 \\
\hline & & Botrylloides niger & 0.00 & 10.77 & 5.89 & 1.58 & 8.61 & 35.58 \\
\hline & & Cradoscrupocellaria bertholletii & 10.61 & 11.62 & 4.21 & 1.50 & 6.15 & 55.97 \\
\hline & & Scruparia sp. & 6.73 & 0.00 & 3.74 & 1.55 & 5.46 & 61.43 \\
\hline & & Spirobranchus triqueter & 10.27 & 11.45 & 3.25 & 1.39 & 4.74 & 66.17 \\
\hline & & Diplosoma listerianum & 4.71 & 3.87 & 2.87 & 1.23 & 4.20 & 70.37 \\
\hline & & Kirchenpaueria halecioides & 4.21 & 0.17 & 2.23 & 2.00 & 3.26 & 73.62 \\
\hline & & Paraleucilla magna & 3.87 & 0.51 & 1.87 & 1.65 & 2.73 & 76.35 \\
\hline & & Perophora listeri & 0.00 & 3.03 & 1.66 & 0.88 & 2.42 & 78.77 \\
\hline
\end{tabular}


Table 3. Cont.

\begin{tabular}{|c|c|c|c|c|c|c|c|c|c|c|c|}
\hline \multirow{2}{*}{ (b) } & \multirow{2}{*}{ Area } & \multirow{2}{*}{ Taxon } & \multicolumn{4}{|l|}{ Sea-Cages } & \multirow{2}{*}{ Taxon } & \multicolumn{4}{|l|}{ Marinas } \\
\hline & & & Av.Abund & Sim/SD & Contrib\% & Cum \% & & Av.Abund & Sim/SD & Contrib\% & Cum $\%$ \\
\hline & \multirow[t]{11}{*}{ SW } & Scrupocellaria sp. & 20.03 & 6.56 & 31.93 & 31.93 & Salmacina dysteri & 8.59 & 1.44 & 15.42 & 15.42 \\
\hline & & Crisia sp. & 19.36 & 3.61 & 25.42 & 57.34 & Spirorbis sp. & 9.76 & 1.07 & 15.05 & 30.46 \\
\hline & & Eudendrium sp. & 11.78 & 2.92 & 16.38 & 73.72 & Schizoporella errata & 10.27 & 0.91 & 12.93 & 43.39 \\
\hline & & Lithophyllum incrustans & 8.42 & 1.37 & 10.34 & 84.06 & Botrylloides niger & 17.34 & 0.36 & 10.23 & 53.62 \\
\hline & & Ectopleura crocea & 3.7 & 0.96 & 3.5 & 87.56 & Lithophyllum incrustans & 5.72 & 2.11 & 10.14 & 63.76 \\
\hline & & Paraleucilla magna & 2.69 & 1.11 & 2.77 & 90.33 & Ericthonius punctatus & 4.71 & 1.38 & 7.91 & 71.67 \\
\hline & & Ericthonius punctatus & 1.85 & 3.15 & 2.56 & 92.89 & Parasmittina alba & 5.56 & 0.78 & 5.88 & 77.55 \\
\hline & & Sycon ciliatum & 1.85 & 3.54 & 2.19 & 95.08 & Symplegma rubra & 11.28 & 0.26 & 5.48 & 83.02 \\
\hline & & & & & & & Spirobranchus triqueter & 2.69 & 2.41 & 4.02 & 87.05 \\
\hline & & & & & & & Prosuberites longispinus & 7.24 & 0.36 & 3.71 & 90.76 \\
\hline & & & & & & & $\begin{array}{l}\text { Mycale (Carmia) } \\
\text { senegalensis }\end{array}$ & 2.02 & 0.65 & 2.36 & 93.12 \\
\hline & \multirow[t]{8}{*}{ SE } & Ericthonius punctatus & 24.91 & 2.98 & 34.99 & 34.99 & $\begin{array}{l}\text { Cradoscrupocellaria } \\
\text { bertholletii }\end{array}$ & 11.62 & 1.4 & 17.04 & 17.04 \\
\hline & & Crisia sp. & 12.29 & 1.97 & 15.19 & 50.18 & Spirobranchus triqueter & 11.45 & 1.88 & 16.8 & 33.84 \\
\hline & & Spirobranchus triqueter & 10.27 & 3.06 & 12.65 & 62.83 & Botrylloides niger & 10.77 & 1 & 14.38 & 48.21 \\
\hline & & Scruparia sp. & 6.73 & 1.11 & 6.39 & 79.15 & Parasmittina alba & 12.46 & 0.68 & 10.04 & 71.85 \\
\hline & & Kirchenpaueria halecioides & 4.21 & 1.83 & 4.72 & 83.87 & Crisia sp. & 4.88 & 1.67 & 6.08 & 77.93 \\
\hline & & Paraleucilla magna & 3.87 & 1.93 & 4.12 & 87.99 & Ericthonius punctatus & 3.87 & 2.08 & 4.96 & 82.89 \\
\hline & & & & & & & Diplosoma listerianum & 3.87 & 0.63 & 3.33 & 86.22 \\
\hline & & & & & & & Salmacina dysteri & 1.18 & 37.18 & 2.3 & 88.52 \\
\hline
\end{tabular}




\section{Discussion}

The increasing number of anthropogenic marine structures, together with aquaculture facilities, will increase submerged artificial structures that inadvertently provide favorable substrates for fouling organisms, including NIS. Theoretically, fouling organisms could be more attracted to aquaculture facilities than the partially enclosed marinas due to the higher organic and nutrient concentration within these facilities [68]. Standard experimental design allowed comparing, for the first time, fouling communities of fish farms and marinas in two regions of Madeira Island (Northeastern Atlantic Region).

A total of 54 species and 18 NIS were identified in the current study, including the new record of the cryptogenic E. capillare (Alder, 1856) and E. punctatus (Spence Bate, 1857). Comparison of the fouling communities between the two aquaculture farms and recreational marinas showed significant differences among species within each artificial environment in both regions. Sea-cages were mostly characterized by cnidarians, whilst in the marinas, bryozoans and chordates were found in higher percentages. Moreover, the number of NIS significantly differed between the types of artificial environments rather than between regions, with a higher presence of NIS in the marinas.

From the 18 NIS identified, 14 NIS were already reported for the same marinas in previous works [33,36]; nonetheless, Bugulina simplex, C. scaura, and P. sculpta were newly recorded in several marinas of Madeira island [34,36,56,64]. Additionally, Prosuberites longispinus, previously reported from the neighboring island of Porto Santo [36], is documented for the first time in Madeira. Most of the NIS observed in the aquaculture sea-cages were also present in the nearby marina, with the exception of Botryllus schlosseri and P. magna. Interestingly, the hydroid Ectopleura crocea was only detected in the sea-cages.

Fouling organisms related to aquaculture facilities such as the non-indigenous P. magna are in agreement with studies developed in the Mediterranean Sea $[9,28,69]$, where it is considered a potential invasive species [70]. The relation of E. crocea with aquaculture activities has been also documented in other areas of the globe, namely Australia, where it can produce adverse effects [71]. Along with Pennaria disticha, Ectopleura spp. have been identified as highly problematic taxon for marine fish farms, also in the Mediterranean Sea [72], due to the asexual reproduction process-hydranth self-detachment (autotomy) - that leads to the release of the tentacled polyp heads in the water column [73]. When liberated, these polyp heads may act as drifting "armed weapons" able to cause harmful injuries on farmed fish skin and gills.

Regarding the new species observed in the current study, the cnidarian E. capillare was exclusively found in the sea-cages of the Madeira SW region. It was first described in the North Sea and it is reported to be nearly cosmopolitan. Reliable records based on nematocyst information belong to NE Atlantic, Greenland, the Mediterranean, Bermudas, southern Africa, and Japan [74]; however, a wider distribution can be also attributed to the NW Atlantic, including the Gulf of Mexico, and New Zealand [75]. Although E. capillare was already documented in Macaronesia, namely along the Canary Islands [61]; this study provides a new record for Madeira, suggesting maritime transport as the primary introduction vector [76].

The amphipod E. punctatus was identified across all surveyed environments and regions of Madeira. Originally described from Wales, the species has a circumglobal distribution in tropical and temperate climates, including the North Atlantic Ocean, the Mediterranean Sea, and the Indian Ocean [75]. In the Mediterranean Sea, E. punctatus has been commonly found in fouling communities associated with aquaculture systems [5,77]. By contrast, it is considered an introduced species in the SW Atlantic, where it has successfully colonized Argentinian harbors [78]. In the Macaronesian region, E. punctatus was reported from soft bottoms across the Canaries [79] and Azores [80], likely spreading its distribution via maritime transport. In this sense, tube-dweller amphipods such as E. punctatus present a high capacity to disperse by attaching the tube to hard substrates, and thus protecting themselves from hostile environmental conditions [81]. This character- 
istic explains that E. punctatus was highly found on the experimental units and, therefore, accounted as a sessile organism.

Our monitoring showed spatial differences between total and native species richness, as the SE region presented a higher species richness, including a higher cover percentage of NIS. Several factors could contribute to these results. The first factor is that the variation in biofouling is predominantly driven by the light and water flow availability and is often related to the infrastructure's depth and orientation [82-84]. The aquaculture operation and the marina of the SE region are located in an enclosed protected bay with shallow depths $(<30 \mathrm{~m})$, mean annual current speeds lower than $0.5 \mathrm{~m} / \mathrm{s}$, and stable water temperature throughout the year [85], providing favorable conditions for most NIS [86]. On the other hand, sea-cages of the SW region are deployed in open waters with greater depths $(>50 \mathrm{~m})$.

Secondly, the spatial distance between environments might affect the species colonization process [87]. The aquaculture facility of the SE region is located approximately $1 \mathrm{~km}$ from the nearby marina, while in the SW region studied, the environments are nearly $4 \mathrm{~km}$ away. According to Alharbi and Petrovskii [87], the invasion success depends on the stepping stone size, location, and length of the unfavorable area. Hence, it is reasonable that the largest distance between habitats and the oceanographic features in the SW region significantly interfere with the species distribution.

Finally, it is known that commercial and recreational vessels are responsible for the transport of some of the most widespread non-native species [29-31]. The SE region presents a big port $(\sim 4 \mathrm{~km})$ with dense international maritime traffic (e.g., container ships, gas tankers, recreational vessels), opposed to the small shelter port of the SW, used mainly by local fishermen. Moreover, considering that the SE port hosts the aquaculture facility's operational boat, therefore subject to increased fouling, this could support the higher number of NIS found on the SE aquaculture facility than the one located at the SW region. Such connectivity between these two pressurized environments highlights the stepping-stone effect, enhancing opportunities for the spread of fouling species, including NIS. In agreement, Canning-Clode et al. [33] underlined in their conclusions that the NIS occurrence in the Madeira biological system is most likely secondary or tertiary introductions resulting from hull fouling (recreational and cruise vessels). Hence, our results suggest that, at least for some particular NIS, the presence of sea-cages could promote the secondary spread from the hotspots of introduction (i.e., marinas/ports). Future assessments would need to address the potential role of aquaculture facilities as drivers during the introduced NIS invasion process, similarly to studies performed in other basins $[9,88,89]$.

\section{Conclusions}

This study allowed us, for the first time, to assess fouling communities and, more importantly, to detect the NIS richness in aquaculture facilities as a potential result of the stepping-stone effect and spread from marinas on Madeira Island. The methodology employed here was shown to be a valuable tool to characterize and compare sessile assemblages in artificial environments with different anthropogenic pressures. Vagile fauna has been underestimated with this experimental approach, even though relevant species have been found. Furthermore, it has contributed to updating the presence of NIS and biodiversity records for Madeira. Indeed, in the future, if experimental plates are intended to be used in offshore aquaculture environments, they would need to be optimized since these sites are typically exposed to strong currents and storms in Macaronesia, which could affect the integrity of the experimental units. Furthermore, complementary studies aimed at assessing the successional pattern of fouling assemblages in aquaculture systems may be of interest, in order to be compared with similar works performed in other recreational marinas [34-37,57,82].

Supplementary Materials: The following are available online at https:/ /www.mdpi.com/article/ 10.3390/jmse9101121/s1, Figure S1: PVC plate (experimental unit). Figure S2: (a) Aquaculture operation, (b) Experimental unit deployed at aquaculture sea-cages. Figure S3: (a) Recreational 
marina, (b) Experimental unit deployed at marina. Figure S4: Experimental unit with biofouling. Credits: P. Ramalhosa.

Author Contributions: Conceptualization, N.N., P.R., S.Á., and L.P.-G.; methodology, N.N., P.R., S.Á., and L.P.-G.; software, P.R.; validation, P.R. and L.P.-G.; formal analysis, I.G.; investigation, P.R. and L.P.-G.; writing-original draft preparation, L.P.-G. and N.N.; writing-review and editing, L.P.-G., P.R., S.Á., I.G., and N.N.; visualization, I.G.; project administration, N.N.; funding acquisition, N.N. and I.G. All authors have read and agreed to the published version of the manuscript.

Funding: This research was supported by the PLASMAR project (MAC/1.1a/030), funded by the European Union's Interreg MAC 2014-2020 Programme. L. Png-Gonzalez was supported by the European Union's LIFE programme in the framework of LIFE-IP INTEMARES project (LIFE15 IPE/ES/000012). S. Álvarez was supported by Agência Regional para o Desenvolvimento da Investigação, Tecnologia e Inovação (ARDITI) in the framework of MIMAR+ project (MAC2/4.6d/249) and OCEANLIT project (MAC2/4.6d/302), funded by the European Union's Interreg MAC 2014-2020 programme. I. Gestoso was financially supported by a post-doctoral grant in the framework of the 2015 ARDITI Grant Programme Madeira 14-20 (Project M1420-09-5369-FSE-000002). P. Ramalhosa was partially funded by the Project Observatório Oceânico da Madeira-OOM (M1420-01-0145-FEDER000001), co-financed by the Madeira Regional Operational Programme (Madeira 14-20) under the Portugal 2020 strategy, through the European Regional Development Fund (ERDF). This study also had the support of Fundação para a Ciência e Tecnologia (FCT), through the strategic project (UIDB/04292/2020) granted to MARE UI\&I.

Institutional Review Board Statement: Not applicable.

Informed Consent Statement: Not applicable.

Data Availability Statement: The datasets used and/or analyzed during the current study are available from the corresponding author.

Acknowledgments: We thank the administrations of the two marinas (Porto Recreio da Calheta and Marina da Quinta do Lorde, Caniçal) for allowing us to survey NIS diversity along the south coast of Madeira. Special thanks to Aquailha Aquacultura Lda.; in particular, to Elvio Pontes and Nuno Malho for their contribution in the operations and logistics of access to the sea-cages. We further thank F. Ramil for the identification of cnidarian samples.

Conflicts of Interest: The authors declare no conflict of interest.

\section{References}

1. Png-Gonzalez, L.; Andrade, C.; Abramic, A.; Nogueira, N. Analysis of the Aquaculture Industry in Macaronesia under MSFD; Technical Report for PLASMAR Project: 2019. Available online: http://hdl.handle.net/10553/55195 (accessed on 12 October 2021).

2. Brito Hernández, A. Biogeografía y conservación de la biodiversidad marina en la Macaronesia. Rev. Acad. Canar. Cienc. 2010, XXII, 215-229.

3. Madruga, L.; Wallenstein, F.; Azevedo, J.M.N. Regional Ecosystem Profile-Macaronesian Region; Technical Report for European Commission: 2016. Available online: https://ec.europa.eu/environment/nature/biodiversity/best/regions/index_en.htm (accessed on 12 October 2021).

4. Direção Regional de Estatística da Madeira. Available online: https:/ / estatistica.madeira.gov.pt (accessed on 27 July 2021).

5. Fernandez-Gonzalez, V.; Sanchez-Jerez, P. Fouling assemblages associated with off-coast aquaculture facilities: An overall assessment of the Mediterranean Sea. Mediterr. Mar. Sci. 2017, 18, 87-96. [CrossRef]

6. Dürr, S.; Watson, D.I. Biofouling and antifouling in aquaculture. In Biofouling; Dürr, S., Thomason, J.C., Eds.; Wiley-Blackwell: West Sussex, UK, 2009; pp. 267-287.

7. Bannister, J.; Sievers, M.; Bush, F.; Bloecher, N. Biofouling in marine aquaculture: A review of recent research and developments. Biofouling 2019, 35, 631-648. [CrossRef] [PubMed]

8. Gansel, L.C.; Plew, D.R.; Endresen, P.C.; Olsen, A.I.; Misimi, E.; Guenther, J.; Jensen, Ø. Drag of clean and fouled net panelsMeasurements and parameterization of fouling. PLOS ONE 2015, 10, e0131051. [CrossRef] [PubMed]

9. Giangrande, A.; Lezzi, M.; Del Pasqua, M.; Pierri, C.; Longo, C.; Gravina, M.F. Two cases study of fouling colonization patterns in the Mediterranean Sea in the perspective of integrated aquaculture systems. Aquacult. Rep. 2020, 18, 1004555. [CrossRef]

10. Fitridge, I.; Dempster, T.; Guenther, J.; de Nys, R. The impact and control of biofouling in marine aquaculture: A review. Biofouling 2012, 28, 649-669. [CrossRef] [PubMed]

11. Glaropoulos, A.; Papadakis, V.M.; Papadakis, I.E.; Kentouri, M. Escape-related behavior and coping ability of sea bream due to food supply. Aquacult. Int. 2012, 20, 965-979. [CrossRef] 
12. Glaropoulos, A.; Papadakis, V.M.; Papadakis, I.E.; Georgara, A.; Kentouri, M. Sea bream interactions toward the aquaculture net due to the presence of micro-fouling. Aquacult. Int. 2014, 22, 1203-1214. [CrossRef]

13. Nunes, A.L.; Katsanevakis, S.; Zenetos, A.; Cardoso, A.C. Gateways to alien invasions in the European seas. Aquat. Invasions 2014, 9, 133-144. [CrossRef]

14. Campbell, M.L.; King, S.; Heppenstall, L.D.; van Gool, E.; Martin, R.; Hewitt, C.L. Aquaculture and urban marine structures facilitate native and non-indigenous species transfer through generation and accumulation of marine debris. Mar. Pollut. Bull. 2017, 123, 304-312. [CrossRef]

15. Simberloff, D.; Martin, J.; Genovesi, P.; Maris, V.; Wardle, D.A.; Aronson, J.; Courchamp, F.; Galil, B.; García-Berthou, E.; Pascal, M.; et al. Impacts of biological invasions: What's what and the way forward. Trends Ecol. Evol. 2013, 28, 58-66. [CrossRef]

16. Mack, R.N.; Simberloff, D.; Lonsdale, W.M.; Evans, H.; Clout, M.; Bazzaz, F.A. Biotic invasions: Causes, epidemiology, global consequences, and control. Ecol. Appl. 2000, 10, 689-710. [CrossRef]

17. Molnar, J.L.; Gamboa, R.L.; Revenga, C.; Spalding, M.D. Assessing the global threat of invasive species to marine biodiversity. Front. Ecol. Environ. 2008, 6, 485-492. [CrossRef]

18. De Mesel, I.; Kerckhof, F.; Norro, A.; Rumes, B.; Degraer, S. Succession and seasonal dynamics of the epifauna community on offshore wind farm foundations and their role as stepping stones for non-indigenous species. Hydrobiologia 2015, 756, 37-50. [CrossRef]

19. Rius, M.; Heasman, K.G.; McQuaid, C.D. Long-term coexistence of non-indigenous species in aquaculture facilities. Mar. Pollut. Bull. 2011, 62, 2395-2403. [CrossRef]

20. Naylor, R.L.; Williams, S.L.; Strong, D.R. Aquaculture-A gateway for exotic species. Science 2001, 294, 1655-1656. [CrossRef]

21. Mineur, F.; Cook, E.J.; Minchin, D.; Bohn, K.; MacLeod, A.; Maggs, C.A. Oceanography and Marine Biology: An Annual Review; Gibson, R.N., Atkinson, R.J.A., Gordon, J.D.M., Hughes, R.N., Eds.; CRC Press: Abingdon, UK, 2012; Volume 50, pp. 189-234.

22. Simkanin, C.; Davidson, I.C.; Dower, J.F.; Jamieson, G.; Therriault, T.W. Anthropogenic structures and the infiltration of natural benthos by invasive ascidians. Mar. Ecol. 2012, 33, 499-511. [CrossRef]

23. Fernandez-Gonzalez, V.; Sanchez-Jerez, P. First occurrence of Caprella scaura Templeton, 1836 (Crustacea: Amphipoda) on off-coast fish farm cages in the Mediterranean Sea. Helgol. Mar. Res. 2014, 68, 187-191. [CrossRef]

24. Astudillo, J.C.; Bravo, M.; Dumont, C.P.; Thiel, M. Detached aquaculture buoys in the SE Pacific: Potential dispersal vehicles for associated organisms. Aquat. Biol. 2009, 5, 219-231. [CrossRef]

25. Gansel, L.C.; Bloecher, N.; Floerl, O.; Guenther, J. Quantification of biofouling on nets: A comparison of wet weight measurements and optical (image analysis) methods. Aquacult. Int. 2017, 25, 679-692. [CrossRef]

26. Ferrario, J.; Caronni, S.; Occhipinti-Ambrogi, A.; Marchini, A. Role of commercial harbours and recreational marinas in the spread of non-indigenous fouling species. Biofouling 2017, 33, 651-660. [CrossRef]

27. Ulman, A.; Ferrario, J.; Occhipinti-Ambrogi, A.; Arvanitidis, C.; Bandi, A.; Bertolino, M.; Bogi, C.; Chatzigeorgiou, G.; Çiçek, B.A.; Deidun, A.; et al. A massive update of non-indigenous species records in Mediterranean marinas. PeerJ 2017, 5, e3954. [CrossRef] [PubMed]

28. Tamburini, M.; Keppel, E.; Marchini, A.; Repetto, M.F.; Ruiz, G.M.; Ferrario, J.; Occhipinti-Ambrogi, A. Monitoring nonindigenous species in port habitats: First application of a standardized North American protocol in the Mediterranean Sea. Front. Mar. Sci. 2021, 8, 700730. [CrossRef]

29. National Exotic Marine and Estuarine Species Information System. Available online: http://invasions.si.edu/nemesis/ (accessed on 27 July 2021).

30. Ulman, A.; Ferrario, J.; Forcada, A.; Seebens, H.; Arvanitidis, C.; Occhipinti-Ambrogi, A.; Marchini, A. Alien species spreading via biofouling on recreational vessels in the Mediterranean Sea. J. Appl. Ecol. 2019, 56, 2620-2629. [CrossRef]

31. Castro, N.; Ramalhosa, P.; Jiménez, J.; Lino, J. Exploring marine invasions connectivity in a NE Atlantic Island through the lens of historical maritime traffic patterns. Reg. Stud. Mar. Sci. 2020, 37, 101333. [CrossRef]

32. Giangrande, A.; Arduini, D.; Borghese, J.; Del Pasqua, M.; Lezzi, M.; Petrocelli, A.; Cecere, E.; Longo, C.; Pierri, C. Macrobenthic success of non-indigenous species related to substrate features in the Mar Grande of Taranto, Italy (Mediterranean Sea). BioInvasions Rec. 2021, 10, 238-256. [CrossRef]

33. Canning-Clode, J.; Fofonoff, P.; McCann, L.; Carlton, J.T.; Ruiz, G. Marine invasions on a subtropical island: Fouling studies and new records in a recent marina on Madeira Island (Eastern Atlantic Ocean). Aquat. Invasions 2013, 8, 1-10. [CrossRef]

34. Ramalhosa, P.; Canning-Clode, J. The invasive caprellid Caprella scaura Templeton, 1836 (Crustacea: Amphipoda: Caprellidae) arrives to Madeira Island, Portugal. BioInvasions Rec. 2015, 4, 97-102. [CrossRef]

35. Gestoso, I.; Ramalhosa, P.; Canning-Clode, J. Biotic effects during the settlement process of non-indigenous species in marine benthic communities. Aquat. Invasions 2018, 13, 247-259. [CrossRef]

36. Ramalhosa, P.; Gestoso, I.; Duarte, B.; Caçador, I.; Canning-Clode, J. Metal pollution affects both native and non-indigenous biofouling recruitment in a subtropical island system. Mar. Pollut. Bull. 2019, 141, 373-386. [CrossRef]

37. Ramalhosa, P.; Gestoso, I.; Rocha, R.; Lambert, G.; Canning-Clode, J. The Ascidian biodiversity of the Madeira Archipelago shallow waters: New records, spatial-temporal distribution, habitat type, and biogeographic notes. Reg. Stud. Mar. Sci. 2021, 43, 101672. [CrossRef]

38. Marraffini, M.; Ashton, G.; Brown, C.; Chang, A.; Ruiz, G. Settlement plates as monitoring devices for non-indigenous species in marine fouling communities. Manag. Biol. Invasions 2017, 8, 559-566. [CrossRef] 
39. Lezzi, M.; Del Pasqua, M.; Pierri, C.; Giangrande, A. Seasonal non-indigenous species succession in a marine macrofouling invertebrate community. Biol. Invasions 2018, 20, 937-961. [CrossRef]

40. Jimenez, H.; Keppel, E.; Chang, A.L.; Ruiz, G.M. Invasions in marine communities: Contrasting species richness and community composition across habitats and salinity. Estuar. Coast. 2018, 41, 484-494. [CrossRef]

41. Canning-Clode, J.; Fofonoff, P.; Riedel, G.F.; Torchin, M.; Ruiz, G.M. The effects of copper pollution on fouling assemblage diversity: A tropical-temperate comparison. PLoS ONE 2011, 6, e18026. [CrossRef] [PubMed]

42. Ramalhosa, P.; Camacho-Cruz, K.; Bastida-Zavala, R.; Canning-Clode, J. First record of Branchiomma bairdi McIntosh, 1885 (Annelida: Sabellidae) from Madeira Island, Portugal (northeastern Atlantic Ocean). BioInvasions Rec. 2014, 3, 235-239. [CrossRef]

43. Carlton, J.T. Pattern, process, and prediction in marine invasion ecology. Biol. Conserv. 1996, 78, 97-106. [CrossRef]

44. Gestoso, I.; Ramalhosa, P.; Oliveira, P.; Canning-Clode, J. Marine protected communities against biological invasions: A case study from an offshore island. Mar. Pollut. Bull. 2017, 119, 72-80. [CrossRef]

45. Chainho, P.; Fernandes, A.; Amorim, A.; Ávila, S.P.; Canning-Clode, J.; Castro, J.J.; Costa, A.C.; Costa, J.L.; Cruz, T.; Gollasch, S.; et al. Non-indigenous species in Portuguese coastal areas, coastal lagoons, estuaries and islands. Estuar. Coast. Shelf Sci. 2015, 167, 199-211. [CrossRef]

46. Kohler, K.E.; Gill, S.M. Coral Point Count with Excel extensions (CPCe): A Visual Basic programme for the determination of coral and substrate coverage using random point count methodology. Comput. Geosci. 2006, 32, 1259-1269. [CrossRef]

47. Airoldi, L.; Turon, X.; Perkol-Finkel, S.; Rius, M. Corridors for aliens but not for natives: Effects of marine urban sprawl at a regional scale. Divers. Distrib. 2015, 21,755-768. [CrossRef]

48. Underwood, A.J. Experiments in Ecology: Their Logical Design and Interpretation Using Analysis of Variance; Cambridge University Press: Cambridge, UK, 1997.

49. Clarke, K.R. Non-parametric multivariate analyses of changes in community. Aust. J. Ecol. 1993, 18, 117-143. [CrossRef]

50. Clarke, K.R.; Gorley, R.N. PRIMER v6: User manual-Tutorial; Plymouth Marine Laboratory: Plymouth, UK, 2006.

51. Anderson, M.J. A new method for non-parametric multivariate analysis of variance. Austral Ecol. 2008, 26, 32-46. [CrossRef]

52. Núñez, J.C.; Talavera, J.A. Fauna of the polychaetous annelids from Madeira. Bol. Mus. Munic. Funchal 1995, 4, 511-530.

53. Langerhans, P. Die Wurmfauna von Madeira. III. Z. Wiss. Zool. 1880, 34, 87-143.

54. Norman, A.M. The Polyzoa of Madeira and neighbouring islands. Zool. J. Linnean Soc. 1909, 30, 275-314. [CrossRef]

55. Wirtz, P.; Canning-Clode, J. The invasive bryozoan Zoobotryon verticillatum has arrived at Madeira Island. Aquat. Invasions 2009, 4 , 669-670. [CrossRef]

56. Ramalhosa, P.; Souto, J.; Canning-Clode, J. Diversity of Bugulidae (Bryozoa, Cheilostomata) colonising artificial substrates in the Madeira Archipelago (NE Atlantic Ocean). Helgol. Mar. Res. 2017, 71, 1. [CrossRef]

57. Souto, J.; Ramalhosa, P.; Canning-Clode, J. Three non-indigenous species from Madeira harbours, including a new species of Parasmittina (Bryozoa). Mar. Biodivers. 2018, 48, 977-986. [CrossRef]

58. Souto, J.; Kaufmann, M.J.; Canning-Clode, J. New species and new records of bryozoans from shallow waters of Madeira Island. Zootaxa 2015, 3925, 581-593. [CrossRef] [PubMed]

59. Wirtz, P. On a collection of hydroids (Cnidaria, Hydrozoa) from the Madeira archipelago. Arquipelago 2007, 24, 11-16.

60. Wirtz, P. Unterwasserführer Madeira, Kanaren, Azoren-Niedere Tiere; Edition Naglschmid: Stuttgart, Germany, 1995.

61. Vervoort, W. Leptolida (Cnidaria: Hydrozoa) collected during the CANCAP and Mauritania-II expeditions of the National Museum of Natural History, Leiden, The Netherlands [Anthoathecata, various families of Leptothecata and addenda]. Zool. Med. Leiden 2006, 80, 181-318.

62. Bianchi, C.N.; Morri, C.; Sartoni, G.; Wirtz, P. Sublittoral epibenthic communities around Funchal (Ilha da Madeira, NE Atlantic). Bol. Mus. Munic. Funchal 1998, 5, 59-80.

63. Wirtz, P. Ten invertebrates new for the marine fauna of Madeira. Arquipelago 2006, 23A, 75-78.

64. Ramalhosa, P.; Nebra, A.; Gestoso, I.; Canning-Clode, J. First record of the non-indigenous isopods Paracerceis sculpta (Holmes, 1904) and Sphaeroma walkeri Stebbing, 1905 (Isopoda, Sphaeromatidae) for Madeira Island. Crustaceana 2017, 90, 1747-1764. [CrossRef]

65. Levring, T. The marine algae of the Archipelago of Madeira. Bol. Mus. Munic. Funchal 1974, $28,5-111$.

66. Neto, A.I.; Cravo, D.C.; Haroun, R.T. Checklist of the Benthic Marine Plants of the Madeira Archipelago. Bot. Mar. 2001, 44, 391-414. [CrossRef]

67. Cruz, T. Esponjas Marinas de Canarias; Gobierno de Canarias: Santa Cruz Tenerife, Spain, 2002.

68. Madin, J.; Chong, V.C.; Hartstein, N.D. Effects of water flow velocity and fish culture on net biofouling in fish cages. Aquac. Res. 2010, 41, e602-e617. [CrossRef]

69. Longo, C.; Mastrototaro, F.; Corriero, G. Occurrence of Paraleucilla magna (Porifera: Calcarea) in the Mediterranean Sea. J. Mar. Biol. Assoc. 2007, 87, 1749-1755. [CrossRef]

70. Bachetarzi, R.; Dilmi, S.; Uriz, M.J.; Vázquez-Luis, M.; Deudero, S.; Rebzani-Zahaf, C. The non-indigenous and invasive species Paraleucilla magna Klautau, Monteiro \& Borojevic, 2004 (Porifera: Calcarea) in the Algerian coast (Southwestern of Mediterranean Sea). Acta Adriat. 2019, 60, 41-46. [CrossRef]

71. Fitridge, I.; Keough, M.J. Ruinous resident: The hydroid Ectopleura crocea negatively affects suspended culture of the mussel Mytilus galloprovincialis. Biofouling 2013, 29, 119-131. [CrossRef] [PubMed] 
72. Bosch-Belmar, M.; Azzurro, E.; Pulis, K.; Milisenda, G.; Fuentes, V.; Kéfi-Daly Yahia, O.; Micallef, A.; Deidun, A.; Piraino, S. Jellyfish blooms perception in Mediterranean finfish aquaculture. Mar. Policy 2017, 76, 1-7. [CrossRef]

73. Bosch-Belmar, M.; Escurriola, A.; Milisenda, G.; Fuentes, V.L.; Piraino, S. Harmful Fouling Communities on Fish Farms in the SW Mediterranean Sea: Composition, Growth and Reproductive Periods. J. Mar. Sci. Eng. 2019, 7, 288. [CrossRef]

74. Schuchert, P. The European athecate hydroids and their medusae (Hydrozoa, Cnidaria): Filifera Part 4. Rev. Suisse De Zool. 2008, 115, 677-757. [CrossRef]

75. World Register of Marine Species. Available online: http:/ /www.marinespecies.org/ (accessed on 19 September 2021).

76. European Alien Species Information Network. Available online: https:/ / easin.jrc.ec.europa.eu/ (accessed on 19 September 2021).

77. Mangano, M.C.; Ape, F.; Mirto, S. The role of two non-indigenous serpulid tube worms in shaping artificial hard substrata communities: Case study of a fish farm in the central Mediterranean Sea. Aquacult. Environ. Interact. 2019, 11, 41-51. [CrossRef]

78. Rumbold, C.E.; Ruiz Barlett, T.; Gavio, M.A.; Obenat, S.M. Population dynamics of two invasive amphipods in the Southwestern Atlantic: Monocorophium acherusicum and Ericthonius punctatus (Crustacea). Mar. Biol. Res. 2016, 12, 268-277. [CrossRef]

79. Png-Gonzalez, L.; Vázquez-Luis, M.; Tuya, F. Comparison of epifaunal assemblages between Cymodocea nodosa and Caulerpa prolifera meadows in Gran Canaria (eastern Atlantic). J. Mar. Biolog. Assoc. UK 2014, 94, 241-253. [CrossRef]

80. Bamber, R.G.; Robbins, R. The soft-sediment infauna off São Miguel, Azores, and a comparison with other Azorean invertebrate habitats. Açoreana 2009, 6, 201-210.

81. Ros, M.; Navarro-Barranco, C.; González-Sánchez, M.; Ostalé-Valriberas, E.; Cervera-Currado, L.; Guerra-García, J.M. Starting the stowaway pathway: The role of dispersal behavior in the invasion success of low-mobile marine species. Biol. Invasions 2020, 22, 2797-2812. [CrossRef]

82. Cronin, E.R.; Cheshire, A.C.; Clarke, S.M.; Melville, A.J. An investigation into the composition, biomass and oxygen budget of the fouling community on tuna aquaculture farm. Biofouling 1999, 13, 279-299. [CrossRef]

83. Howes, S.; Herbinger, C.M.; Darnell, P.; Vercaemer, B. Spatial and temporal patterns of recruitment of the tunicate Ciona intestinalis on a mussel farm in Nova Scotia, Canada. J. Exp. Mar. Biol. Ecol. 2007, 342, 85-92. [CrossRef]

84. Guenther, J.; Misimi, E.; Sunde, L.M. The development of biofouling, particularly the hydroid Ectopleura larynx, on commercial salmon cage nets in Mid-Norway. Aquaculture 2010, 300, 120-127. [CrossRef]

85. Andrade, C.A.P. A fish farm pilot-project in Madeira Archipelago, Northeastern Atlantic-II. Environment impact assessment. In Proceedings of the International Conference: Open Ocean Aquaculture, Portland, OR, USA, 8-10 May 1996; Polk, M., Ed.; pp. 377-382.

86. Galil, B.S. Alien species in the Mediterranean Sea-Which, when, where, why? Hydrobiologia 2008, 606, 105-116. [CrossRef]

87. Alharbi, W.; Petrovskii, S. Effect of complex landscape geometry on the invasive species spread: Invasion with stepping stones. J. Theor. Biol. 2019, 464, 85-97. [CrossRef]

88. Lezzi, M.; Giangrande, A. Seasonal and bathymetric effects on macrofouling invertebrates' primary succession in a Mediterranean non-indigenous species hotspot area. Mediterr. Mar. Sci. 2018, 19, 572-588. [CrossRef]

89. Pica, D.; Bloecher, N.; Dell'Anno, A.; Bellucci, A.; Pinto, T.; Pola, L.; Puce, S. Dynamics of a biofouling community in finfish aquaculture: A case study from the South Adriatic Sea. Biofouling 2019, 35, 696-709. [CrossRef] 